\title{
DESKRIPSI KONSEPSI SISWA SMA TENTANG RANGKAIAN LISTRIK ARUS SEARAH
}

\author{
Andhika Nugraha ${ }^{1}$, I Komang Werdhiana ${ }^{2}$, dan I Wayan Darmadi ${ }^{3}$ \\ Email: andhika_entrepreneur@yahoo.com \\ Program Studi Pendidikan Fisika, Jurusan Pendidikan MIPA, Universitas Tadulako \\ JI. Soekarno Hatta KM.9 Kampus Bumi Tadulako Tondo Palu - Sulawesi Tengah
}

\begin{abstract}
Abstrak - Penelitian ini bertujuan untuk untuk mendeskripsikan konsepsi siswa SMA tentang rangkaian listrik arus searah. Responden yang terlibat dalam penelitian ini sebanyak 35 siswa. Instrumen yang digunakan untuk mendeksripsikan konsepsi ialah "DIRECT versi 1.0" (Determining and Interpreting Resistive Electric Circuit Test) sebanyak 24 nomor. Pada tahap pertama siswa diharapkan memilih pilihan yang tepat sesuai jumlah pilihan yang ada. Pada tahap kedua siswa diminta untuk memberikan alasan atau penalaran mereka pada jawaban yang dipilihnya. Presentasi jawaban dan alasan yang dikemukakan siswa dianalisis serta mewawancarai 9 responden berdasarkan kategori tinggi, sedang, dan rendah. Hasil penelitian menunjukkan konsepsi siswa terhadap rangkaian listrik arus searah masih rendah khususnya yang berhubungan dengan hubungan singkat pada rangkaian, Hukum Kirchoff 1 dan medan listrik serta ditemukannya miskonsepsi pada rangkaian listrik arus searah antara lain (a) adanya arus listrik yang mengalir dalam rangkaian walaupun saklar telah diputuskan, (b) besarnya kuat arus yang melewati hambatan pada rangkaian seri dan paralel adalah sama, dan (c) arus listrik yang mengalir dalam rangkaian paralel di semua titik adalah sama.
\end{abstract}

Kata Kunci: Konsepsi, Rangkaian Listrik Arus Searah.

\section{PENDAHULUAN}

Fisika merupakan suatu disiplin ilmu yang mempelajari fenomena alam semesta, hukumhukum, dan interaksinya. Setiap gejala alam apa saja pasti terkait dengan hukum fisika. Berdasarkan hal tersebut fisika tidaklah lepas dari apa yang terjadi di alam semesta ini dan selalu berkaitan dengan kehidupan sehari-hari. Hal ini menuntut siswa mampu menyelesaikan masalah dalam realita kehidupan dengan menerapkan pengetahuan fisika yang dimilikinya

Dalam 20 tahun terakhir ini cukup banyak penelitian pendidikan yang berkaitan dengan konsepsi siswa dari berbagai topik [1]. Penelitian yang dilakukan Saleh, S tentang pemahaman konsep Newtonian terhadap mahasiswa diperoleh hasil bahwa masih terdapat permasalahan secara konseptual memahami konsep fisika yang diajarkan pada mahasiswa [2]. Penelitian terhadap pemahaman siswa yang dilakukan Engelhardt P. V. \& Beichner, R. J. terhadap konsep dari rangkaian arus listrik searah diperoleh hasil bahwa terdapatnya miskonsepsi [3]

Penelitian terhadap rangkaian arus listrik searah banyak ditemukan miskonsepsi yang antara lain: 1) arus, energi dan perbedaan potensial tidak dianggap sebagai konsep yang berbeda dan digunakan bergantian satu sama lain. 2) arus digunakan dalam komponen rangkaian; 3) arus keluar dari kutub positif pada baterai dan masuk ke dalam bohlam yang digunakan untuk menerangi bohlam, sedangkan kabel penghubung pada ujung kutub negatif baterai dan bola lampu tidak ada gunanya sama sekali; 4) arus keluar dari kedua kutub yang menyebabkan kedua arus bertemu dan membuat lampu menjadi menyala; 5) arus mengalir secara merata pada rangkaian paralel; 6) baterai adalah sumber arus konstan [4]

Konsepsi sebagai kemampuan memahami konsep, baik yang diperoleh melalui interaksi dengan lingkungan maupun konsep yang diperoleh dari pendidikan sekolah [5]. Pada umumnya siswa memiliki visualisasi yang tidak lengkap dan tidak konsisten tentang suatu konsep [6]. Konsepsi itu sendiri terbentuk pada masa anak-anak tersebut dalam interaksi otak dengan lingkungannya. Hal ini dikarenakan siswa telah berpengalaman dengan peristiwaperistiwa fisika dalam kehidupan sehariharinya.

Berdasarkan hal tersebut peneliti melaksanakan penelitian tentang konsepsi siswa pada rangkaian arus listrik searah yang dimana pada penelitian ini menggunakan instrumen yang bernama "DIRECT versi 1.0 " (Determining and Interpreting Resistive Electric Circuit Test) [7]. Tes ini terdiri dari soal berjumlah 24 nomor. Tes ini dapat digunakan mengevaluasi kurikulum atau metode pengajaran serta memberikan wawasan 
ISSN 23383240

pemahaman konsep siswa terhadap fenomena rangkaian listrik arus searah. Pada penelitian ini, "DIRECT versi 1.0" digunakan untuk mengetahui konsepsi siswa yang dimiliki khususnya pada rangkaian arus listrik searah.

\section{PETUNJUK BERGUNA}

Penelitian ini merupakan penelitian kualitatif dengan menggunakan pendekatan deskriptif kualitatif. Penelitian ini dilaksanakan di salah satu sekolah negeri di Kota Palu dengan subjek sebanyak 35 siswa dan responden yang diwawancarai sebanyak 9 siswa untuk menelusuri konsep siswa tentang rangkaian listrik arus searah.

Instrumen yang digunakan pada penelitian ini adalah "DIRECT versi 1.0" (Determining and Interpreting Resistive Electric Circuit Test) dengan jenis Soal Pilihan Ganda Beralasan. Untuk menghitung presentase pemilihan tiap option per butir soal digunakan persamaan:

$$
A=\frac{x}{\mathrm{n}} \times 100 \%
$$

\section{Dengan}

A : Persentase pemilihan setiap option

$\mathrm{x}$ : Jumlah siswa yang memilih option

$n$ : Banyaknya peserta tes

Persentase dari setiap pilihan responden untuk setiap pilihan akan dianalisis. Dalam analisis dari setiap pilihan soal A, B, C, D dan E yang terdapat pada masing-masing soal merupakan pilihan dari para responden. Untuk menilai penjelasan responden dari alasan pilihan jawaban dan wawancara, digunakan empat kriteria untuk tingkat konsepsi siswa [8], yaitu:

\begin{tabular}{|c|c|c|c|c|}
\hline \multirow{2}{*}{$\begin{array}{l}\mathrm{N} \\
\mathrm{o} \\
\mathrm{m} \\
\text { or }\end{array}$} & \multicolumn{4}{|c|}{ Tingkat Pemahaman Konsep ( $\%$ ) } \\
\hline & $\begin{array}{c}\text { Penjelasan } \\
\text { benar }\end{array}$ & $\begin{array}{l}\text { Penjelasan } \\
\text { salah }\end{array}$ & $\begin{array}{c}\text { Penjelasan } \\
\text { yang tidak } \\
\text { sesuai }\end{array}$ & $\begin{array}{l}\text { Tidak ada } \\
\text { Penjelasan }\end{array}$ \\
\hline 1 & & & & \\
\hline 2 & & & & \\
\hline$\ldots$ & & & & \\
\hline $\mathrm{n}$ & & & & \\
\hline
\end{tabular}

a. Penjelasan Benar:

Penjelasan siswa yang mencakup semua komponen dari ide-ide ilmiah yang dapat diterima.

b. Penjelasan Salah:

Penjelasan siswa yang tidak dapat diterima secara ilmiah

c. Penjelasan Yang Tidak Sesuai:

Penjelasan siswa yang tidak sesuai dengan kategori A dan kategori B.

d. Tidak Ada Penjelasan:
Siswa yang tidak menuliskan penjelasan sesuai dengan pilihannya atau menulis ulang kembali pilihannya.

\section{HASIL DAN PEMBAHASAN}

Adapun hasil penelitian yang diperoleh disajikan pada Tabel 2 berikut:

\begin{tabular}{|c|c|c|c|c|c|c|c|c|c|}
\hline \multirow[b]{2}{*}{ No } & \multicolumn{5}{|c|}{ Presentase Pemilihan Jawaban (\%) } & \multicolumn{4}{|c|}{ Presentasi Setiap Alasan (\%) } \\
\hline & A & B & C & D & $E$ & $\begin{array}{c}\text { Penjelasan } \\
\text { Benar }\end{array}$ & $\begin{array}{c}\text { Penjelasan } \\
\text { Salah }\end{array}$ & \begin{tabular}{c|} 
Penjelasan \\
Yang Tidak \\
Sesuai \\
\end{tabular} & $\begin{array}{l}\text { Tidak Ada } \\
\text { Penjelasan }\end{array}$ \\
\hline 1 & 0,00 & 0,00 & 85,71 & 0,00 & 11,43 & 0,00 & 85,71 & 11,43 & 2,86 \\
\hline 2 & 8,57 & 45,71 & 37,14 & 5,71 & 2,86 & 5,71 & 60,00 & 22,86 & 11,43 \\
\hline 3 & 31,43 & 54,29 & 11,43 & & & 25,71 & 34,29 & 34,29 & 5,71 \\
\hline 4 & 42,86 & 40,00 & 17,14 & & & 2,86 & 57,14 & 17,14 & 22,86 \\
\hline 5 & 8,57 & 14,29 & 2,86 & 74,29 & & 0,00 & 85,71 & 2,86 & 11,43 \\
\hline 6 & 14,29 & 2,86 & 20,00 & 31,43 & 22,86 & 17,14 & 54,29 & 17,14 & 11,43 \\
\hline 7 & 94,29 & 5,71 & 0,00 & 0,00 & 0,00 & 25,71 & 0,00 & 65,71 & 8,57 \\
\hline 8 & 20,00 & 65,71 & 8,57 & & & 51,43 & 25,71 & 11,43 & 11,43 \\
\hline 9 & 48,57 & 20,00 & 11,43 & 5,71 & 5,71 & 0,00 & 60,00 & 25,71 & 14,29 \\
\hline 10 & 20,00 & 20,00 & 37,14 & 0,00 & 11,43 & 22,86 & 31,43 & 20,00 & 11,43 \\
\hline 11 & 14,29 & 5,71 & 17,14 & 51,43 & 2,86 & 34,29 & 37,14 & 11,43 & 8,57 \\
\hline 12 & 51,43 & 2,86 & 42,86 & & & 2,86 & 77,14 & 11,43 & 2,86 \\
\hline 13 & 5,71 & 37,14 & 37,14 & 2,86 & 2,86 & 0,00 & 57,14 & 17,14 & 25,71 \\
\hline 14 & 31,43 & 8,57 & 0,00 & 57,14 & & 0,00 & 34,29 & 28,57 & 37,14 \\
\hline 15 & 5,71 & 14,29 & 62,86 & 11,43 & & 0,00 & 25,71 & 11,43 & 62,86 \\
\hline 16 & 74,29 & 11,43 & 14,29 & & & 62,86 & 17,14 & 14,29 & 2,86 \\
\hline 17 & 20,00 & 28,57 & 42,86 & & & 2,86 & 51,43 & 25,71 & 20,00 \\
\hline 18 & 80,00 & 8,57 & 8,57 & & & 45,71 & 25,71 & 20,00 & 8,57 \\
\hline 19 & 31,43 & 0,00 & 11,43 & 8,57 & 37,14 & 2,86 & 40,00 & 11,43 & 45,71 \\
\hline 20 & 65,71 & 14,29 & 14,29 & & & 11,43 & 62,86 & 11,43 & 14,29 \\
\hline 21 & 34,29 & 28,57 & 20,00 & 2,86 & 5,71 & 0,00 & 20,00 & 5,71 & 74,29 \\
\hline 22 & 17,14 & 8,57 & 54,29 & 8,57 & & 2,86 & 54,29 & 14,29 & 28,57 \\
\hline 23 & 28,57 & 22,86 & 11,43 & 14,29 & 14,29 & 5,71 & 60,00 & 20,00 & 14,29 \\
\hline 24 & 31,43 & 8,57 & 8,57 & 31,43 & 5,71 & 11,43 & 51,43 & 5,71 & 25,71 \\
\hline
\end{tabular}

Bersumber pada hasil tabel diketahui bahwa, terdapat 7 soal yang responden tidak dapat memberikan alasan dengan benar berdasarkan konsep yang tepat. Adapun nomor-nomor soal yang dimaksud ialah pada nomor 1, 5, 9, 13, 14, 15 dan 21. Selain itu, pada nomor 5, 9, 13, 21 dan 22 merupakan soal yang jumlah respondennya yang memilih pilihan yang tepat sangat sedikit.

Penelitian ini untuk mengetahui sejauh mana konsepsi yang dimiliki oleh responden tentang konsep rangkaian listrik arus searah dengan menggunakan instrumen DIRECT versi 1.0. Responden yang terlibat dalam wawancara sebanyak 9 responden yang diperoleh dengan menghitung nilai rata-rata dan standar sehingga diperoleh kategori tinggi, sedang dan rendah. adapun nilai rata-rata dan standar deviasi ialah 8,45 dan 2,10.

\section{Hubungan Singkat pada Rangkaian}

Hasil analisis pada soal nomor 1 hanya terdapat 4 siswa yang menjawab sesuai dengan 
ISSN 23383240

pilihan jawaban benar yaitu lampu A sama dengan lampu $C(E . A=C)$ dengan persentasi $11,43 \%$ dengan tiga responden memberikan alasan yang tidak dapat diterima secara ilmiah dan satu responden yang penjelasannya tidak jelas. Penjelasan yang tidak dapat diterima secara ilmiah disebabkan responden tidak memberikan penjelasan yang berhubungan dengan hubungan singkat. Berdasarkan alasan yang diungkapkan, tidak ada satupun alasan yang menjelaskan bahwa adanya hubungan singkat pada Rangkaian 1 yang menyebabkan arus tidak mengalir pada lampu $B$ sehingga menyebabkan nyala lampu A pada Rangkaian 1 dan lampu $C$ di Rangkaian 2 adalah sama.

Pada umumnya siswa memilih Jawaban C dengan persentasi sebesar $85,71 \%$ dengan alasan hanya melihat dari jumlah lampu yang terdapat pada rangkaian sehingga responden lebih banyak memilih Rangkaian 2 karena terdiri dari sebuah lampu dengan 1 baterai dibandingkan Rangkaian 1 yang tersusun atas 2 lampu dengan 1 baterai. Hasil wawancara menunjukkan informasi bahwa responden hanya menjelaskan dari segi pengamatan semata terhadap gambar tanpa disertai adanya konsep hubungan singkat.

Hal yang sama diperoleh pada soal Nomor 2 tentang hubungan singkat, siswa umumnya tidak memahami tentang hubungan singkat. Hal ini dikarenakan persentasi penjelasan salah yang cukup besar mencapai 60,00\% dengan menganggap bahwa penambahan kawat akan mempengaruhi nyala lampu.

\section{Hambatan pada Rangkaian Seri dan Paralel}

Pada soal Nomor 5 tentang bagaimana hambatan pada lampu ketika saklar pada rangkaian yang tersusun secara seri diputuskan. Hasil yang diperoleh hanya satu responden yang menjawab benar dengan persentasi sebesar 2,86\%. Namun jika ditinjau dari segi alasan, responden menjawab dengan alasan yang tidak dapat diterima secara ilmiah. Alasan yang tepat untuk soal Nomor 5 ialah kondisi rangkaian tidak berpengaruh pada hambatan lampu. Hambatan lampu merupakan karakteristik dari lampu tersebut sehingga tidak dipengaruhi oleh kondisi apapun.

Persentasi siswa yang menjawab bahwa hambatan menuju nol ketika saklar tersebut diputuskan sebesar $85,71 \%$, umumnya alasan yang dipaparkan responden disebabkan ketika saklar diputuskan secara otomatis hambatannya akan menuju ke nol karena tidak adanya arus listrik yang mengalir. Pernyataan yang sama juga diperoleh ketika peneliti mewawancarai salah seorang responden yang mengatakan apabila rangkaian teputus hambatannya menurun menuju ke nol dan jika rangkaian terhubung nilai hambatannya bertambah.

Pada soal Nomor 3 dan Nomor 4 yang memiliki indikator yang sama dengan soal nomor 5, sebagian responden hanya memahami sebatas apabila rangkaian terhubung secara seri nilai hambatannya akan mengalami peningkatan sedangkan rangkaian paralel mengalami penurunan.

\section{Menginterpretasikan Rangkaian Listrik Arus Searah}

Hasil analisis pada soal Nomor 6 diketahui bahwa ada 11 siswa yang menjawab pilihan yang menyatakan bahwa Rangkaian A dan C yang merupakan rangkaian paralel dan kedua lampu tersebut dalam keadaan menyala dengan persentasi sebesar $31,43 \%$. Namun dari persentasi tersebut, hanya ada 6 responden yang menjawab sesuai dengan konsep yang menyatakan bahwa Rangkaian A dan C merupakan rangkaian paralel yang terdiri dari dua lampu yang sedang menyala sedangkan Rangkaian B merupakan rangkaian seri sedangkan Rangkaian D merupakan paralel namun rangkaian tersebut hanya akan menyalakan satu lampu karena terjadi hubungan pendek..

Responden yang mengatakan bahwa rangkaian paralel yaitu Rangkaian A dengan persentasi sebesar $14,29 \%$ atau rangkaian paralel hanya Rangkaian C sebesar 20,00\% sedangkan responden yang menjawab rangkaian paralel yaitu Rangkaian A, C dan D sebesar $22,86 \%$. Responden yang menganggap bahwa Rangkaian D merupakan rangkaian paralel yang terdiri dari dua lampu yang menyala umumnya hanya meninjau dari rangkaian tanpa melihat adanya hubungan singkat.

Pada soal Nomor 7 yang mempunyai indikator sama dengan Nomor 6 tentang menginterpretasikan rangkaian umumnya responden telah memahami. Hal ini dapat dilihat pada persentasi responden yang memilih pilihan tepat sebesar $94,29 \%$. Namun, sebagian besar responden tidak mampu menjelaskan rangkaian dalam bentuk pernyataan.

\section{Daya}

Pada soal Nomor 9, hasil yang diperoleh menunjukkan hanya 2 responden yang 
ISSN 23383240

menjawab pilihan yang tepat yaitu Rangkaian 1 sama dengan Rangkaian 2 dengan persentasi sebesar $5,71 \%$. Tetapi kedua siswa tidak mampu menjelaskan alasan kenapa sampai memilih Pilihan D. Bahkan salah seorang responden mengatakan $\mathrm{Hal}$ ini dikarenakan pada Rangkaian 1 dan Rangkaian 2 memiliki daya paling kecil walaupun Rangkaian 3 sama dengan Rangkaian 2 yang tersusun atas dua buah tegangan. Hal ini disebabkan pada Rangkaian 2, tegangannya tersusun secara paralel bahwa besarnya nilai tegangannya adalah sama sedangkan pada Rangkaian 3 tersusun secara seri yang besarnya nilai tegangannya merupakan jumlah dari masingmasing tegangan sehingga besarnya nilai tegangan pada Rangkaian 1 sama dengan Rangkaian 2. Berdasarkan hal tersebut, tegangan berbanding lurus dengan daya sehingga rangkaian 1 dan rangkaian 2 memiliki daya yang paing kecil.

Responden pada umumnya memilih Jawaban A yaitu rangkaian seri dengan persentasi sebesar 48,57\% dengan anggapan bahwa hanya satu baterai yang digunakan tanpa memperhatikan rangkaian paralel yang besarnya tegangan disemua percabangan adalah sama. Hasil yang sama diperoleh ketika salah seorang responden yang memilih Pilihan A diwawancarai untuk mengetahui konsepsi yang dimilikinya. responden menyatakaan Pilihan A umumnya kurang memahai konsep daya.

Pada soal Nomor 9 apabila dihubungkan dengan soal Nomor 8 tentang pengaruh daya pada rangkaian diperoleh perbedaan yang signifikan. Pada soal Nomor 8 persentasi siswa yang memberikan alasan benar tentang konsep daya mencapai $51,43 \%$ sedangkan pada soal Nomor 9 tidak ada siswa yang mampu memberikan alasan yang tepat. Tingginya persentasi konsepsi tentang daya pada soal Nomor 8 karena responden hanya memahami bahwa bahwa ketika ditambahkan hambatan pada suatu rangkaian akan mengalami penurunan daya tanpa mengetahui arti dari konsep daya.

\section{Pemahaman Konseptual pada Kekekalan Energi dan Baterai sebagai Sumber Energi}

Pada soal nomor 10 tentang besarnya energi pada tiga rangkaian diperoleh hasil bahwa hanya sebesar $37,14 \%$ memilih pilihan $C$ sesuai dengan pilihan yang tepat yang menyatakan Rangkaian 3 merupakan rangkaian seri yang tersusun atas 2 buah baterai sedangkan jika dibandingkan Rangkaian 1 hanya tersusun 1 buah baterai dan apabila meninjau Rangkaian 2 yang merupakan rangkaian paralel dapat diketahui bahwa rangkaian yang memiliki energi terbesar ialah Rangkaian 3. Penjelasan ini sesuai dengan konsep bahwa pada Rangkaian 3 memiliki dua buah sumber tegangan dibandingkan Rangkaian 1 yang yang disusun secara seri sehingga tegangan pada Rangkaian 3 lebih besar daripada Rangkaian 1 yang menyebabkan semakin besar energi yang mengalir pada rangkaian tersebut tiap sekon. sedangkan pada Rangkaian 2 merupakan rangkaian yang sumber tegangannya disusun secara paralel sehingga besar beda potensialnya adalah sama. Namun dari presentasi tersebut hanya 8 responden yang menjawab sesuai dengan alasan yang tepat dengan persentasi $22,86 \%$.

Siswa lainnya umumnya memilih Plihan A dan $B$ dengan persentasi yang sama sebesar $20,00 \%$. Responden yang memilih pilihan $A$ umumnya menjelaskan Rangkaian 1 memiliki energi terbesar tiap sekonnya dikarenakan baterai tersebut dapat menyalakan dua buah lampu dengan sebuah baterai. Responden yang memilih pilihan B menjelaskan bahwa rangkaian tersebut memiliki dua buah hambatan dan jalur dari rangkaian tersebut yang teratur sehingga memiliki energi terbesar.

Pada soal Nomor 11 berkaitan dengan soal Nomor 10 disebabkan memiliki indikator yang sama membahas tentang energi. Responden sebagian kecil telah memahami penggunaan energi pada rangkaian paralel dan seri namun dari persentasi tersebut. Sedangkan sebagian lainnya kurang memahami konsep tentang energi apabila sumber tegangan dan hambatannya disusun secara seri atau paralel.

\section{Kekekalan Arus dalam Berbagai Rangkaian}

Pada soal Nomor 13 diperoleh hasil bahwa hanya 1 responden dengan persentasi sebesar $2,86 \%$ yang menjawab pilihan bahwa titik yang tertinggi sampai yang terendah ialah $5=6$, $1=2=3=4$. Adapun konsep yang tepat untuk soal ini ialah disebabkan sesuai dengan bunyi Hukum Kirchoff 1 bahwa kuat arus yang masuk pada titik percabangan sama dengan besarnya kuat arus yang keluar dari titik percabangan. Pada rangkaian, titik 5 dan 6 memiliki arus tertinggi karena pada titik 5 arus tersebut belum memasuki titik percabangan sedangkan pada titik 6 arus terkumpul kembali setelah melewati titik percabangan. Adapun ketika memasuki titik percabangaan arusnya akan 
ISSN 23383240

terbagi ke kedua percabangan tersebut. Responden yang menjawab pilihan $D$ tidak dapat memberikan alasan yang jelas hanya mengulang kembali maksud dari pertanyaan soal tersebut.

Persentasi tingkat kesalahan konsep adalah $57,14 \%$. Umumnya responden menjawab Pilihan $B$ dan $C$ dengan persentasi sama yaitu $37,14 \%$. Berikut ini hasil konsepsi dari alasan dan wawancara terhadap responden umumnya tidak memahami Hukum Kirchoff 1 sehingga menganggap bahwa arus listrik yang mengalir ke rangkaian paralel di semua percabangan sama.

Soal Nomor 12 memiliki keterkaitan dengan soal Nomor 13, hal ini disebabkan kedua soal tersebut membahas tentang hukum kekekalan arus. Hasil yang diperoleh pada soal Nomor 12 menunjukkan hanya terdapat 1 responden yang mampu memberikan alasan yang tepat tentang besarnya arus di ketua titik rangkaian seri. Sedangkan persentasi alasan yang salah dalam soal Nomor 12 ialah 77,14\%. Pada umumnya responden menjelaskan bahwa Titik 1 belum melewati sebuah hambatan sehingga memiliki arus terbesar.

\section{Aspek Mikroskopis Aliran Arus dalam Sebuah Rangkaian}

Pada soal nomor 15 diperoleh hasil bahwa hanya 4 responden yang menjawab Pilihan $D$ dengan persentasi sebesar $11,43 \%$. Berdasarkan persentasi tersebut menunjukkan tidak ada responden yang menjawab dengan alasan yang benar bahwa medan yang ada berasal dari kuat arus yang mengalir. Adanya muatan ini menghasilkan beda potensial sehingga munculnya gaya listrik pada daerah disekitar filamen lampu. Pada umumnya siswa yang menjawab Pilihan $D$ hanya menjelaskan kembali maksud dari pernyataan Pilihan $D$ atau tidak memberikan alasan sama sekali.

Persentasi sebesar $62,86 \%$ ketika sejumlah siswa memilih Pilihan $\mathrm{C}$ menunjukkan umumnya menjawab pilihan bahwa medan listrik tidak nol karena rangkaian terhubung dan arus mengalir. Apabila meninjau siswa yang memberikan alasan terhadap Pilihan $C$, umumnya siswa menjawab karena adanya arus listrik yang berasal dari sumber tegangan sehingga medan listrik tersebut tidak akan nol. Saat wawancara terhadap responden diperoleh hasil bahwa responden tidak memahami maksud dari pertanyaan soal disebabkan responden tidak mengetahui tentang medan listrik
Soal Nomor 14 memiliki keterkaitan dengan soal Nomor 15, hal ini disebabkan kedua nomor tersebut membahas tentang aspek mikroskopis aliran arus dalam sebuah rangkaian melalui penggunaan istilah elektrostatik seperti medan listrik, beda potensial, dan interaksi gaya pada muatan partikel. Adapun hasil analisis pada soal Nomor 14 sama dengan soal Nomor 15 bahwa tidak ada siswa yang mampu menjelaskan secara miskroskopis aliran arus dalam rangkaian. Siswa yang menjawab benar pilihan tepat pada soal Nomor 14 umumnya tidak mampu memberikan penjelasan bahkan memberikan alasan yang tidak dapat diterima secara ilmiah.

\section{Jumlah Arus dipengaruhi oleh Beda Potensial Baterai dan Hambatan pada Rangkaian}

Pada soal Nomor 17, hasil yang diperoleh ialah $51,43 \%$ siswa yang menjawab bahwa nyala dari kedua lampu tersebut akan sama redupnya. Berdasarkan persentasi sebelumnya, hanya seorang siswa yang menjawab sesuai dengan alasan yang tepat menyatakan bahwa lampu A di Rangkaian 1 dan 2 memiliki beda potensial yang sama besar walaupun pada Rangkaian 2 terdiri dari dua buah sumber tegangan. Namun tidak menyebabkan lampu A di Rangkaian 1 lebih redup karena lampu A di Rangkaian 2 tersusun atas sumber tegangan yang tersusun secara paralel.

Umumnya responden salah memaknai sebuah konsep dengan persentasi kesalahan konsep sebesar $51,43 \%$. Adapun hasil analisis terhadap alasan dan wawancara terhadap responden yang memilih jawaban A bahwa kedua lampu akan redup mengungkapkan pada rangkaian paralel menggunakan dua buah sumber tegangan dan dua buah lampu sedangkan pada rangakaian seri hanya menggunakan sebuah baterai untuk sebuah lampu. Adapun responden yang menjawab Pilihan B menganggap bahwa lampu di Rangkaian 2 akan redup karena rangkaian tersebut merupakan rangkaian paralel.

Soal Nomor 16 dan 18 merupakan soal yang mempunyai indikator sama dengan soal Nomor 17. Namun apabila ditinjau konsepsi responden pada soal Nomor 16 dan 18 dibandingkan dengan soal Nomor 17 diperoleh perbedaan yang sangat signifikan. Tingginya persentasi siswa yang memilih pilihan yang tepat dan alasan yang diberikan menunjukkan umumnya siswa telah memahami konsep jumlah arus yang dipengaruhi oleh beda potensial baterai dan hambatan pada rangkaian. Hal ini 


\section{Jurnal Pendidikan Fisika Tadulako (JPFT) \\ Vol. 1 No. 3}

ISSN 23383240

dikarenakan siswa umumnya telah memahami bahwa apabila banyaknya hambatan dan sumber tegangan berpengaruh pada rangkaian seri sedangkan pada soal Nomor 17 siswa tidak memahami konsep tentang arus listrik yang mengalir pada rangkaian paralel.

\section{Beda Potensial}

Pada soal nomor 21 diperoleh hasil bahwa hanya seorang responden dengan persentasi $2,86 \%$ yang memilih pilihan yang tepat yaitu Pilihan D bahwa beda potensial tidak akan bertambah dua kali ketika arusnya dua kali lipat karena beda potensial adalah sifat baterai. Namun alasan yang dikemukakan oleh siswa tersebut menunjukkan bahwa siswa tidak dapat memberikan penjelasan kenapa memilih pilihan tersebut. Konsep pada soal nomor 21 karena setiap sumber tegangan seperti baterai, telah memiliki beda potensial sehingga tidak berpengaruh ketika arus yang melewati sebuah baterai dilipatgandakan. Adapun responden tersebut tidak memberikan alasan sama sekali, atas pilihannya tersebut.

Pada umumnya siswa tidak memberikan penjelasan atau mengulang kembali pernyataan pilihan yang dipilihnya dengan persentasi sebesar $74,29 \%$. Adapun persentasi penjelasan salah sebesar 20,00\%. Responden yang memilih Pilihan A umumnya memberikan penjelasan beda potensial akan dua kali lipat berdasarkan Hukum Ohm. Hal ini disebabkan beda potensial berbanding lurus dengan kuat arus. Adapun hasil wawancara terhadap responden menunjukkan responden hanya terfokus pada Hukum Ohm yang menyatakan arus dan beda potensial berbanding lurus sedangkan responden tidak memahami maksud dari pernyataan soal tersebut.

Pada soal Nomor 21 memiliki indikator yang sama dengan soal Nomor 19, 20, 22, dan 23. Soal Nomor 20, 22, dan 23 tentang beda potensial pada rangkaian paralel dan seri, responden umumnya tidak mengetahui konsep beda potensial pada rangkaian paralel dan seri. Alasan dari responden pada soal Nomor 20 menganggap bahwa dalam rangkaian paralel beda potensial akan terbagi dalam percabangan sehingga ketika salah satu percabangan dihilangkan beda potensial akan mengalir sepenuhnya ke rangkaian yang masih terhubung. sedangkan pada soal Nomor 22 bahwa beda potensialnya menjadi 6 dikarenakan beda potensialnya terbagi dua berdasarkan banyaknya hambatan tanpa meninjau bahwa rangkain tersebut dalam keadaan terputus

\section{Kekekalan Arus dan Konsep Beda Potensial dalam Berbagai Rangkaian}

Pada soal Nomor 24 diperoleh hasil yang diperoleh menunjukkan terdapat 11 siswa dengan persentasi sebesar $31,43 \%$ yang memilih pilihan yang tepat bahwa lampu $A$ dan B menurun. Persentasi siswa yang menjawab sesuai dengan konsep sebesar hanya $11,43 \%$ bahwa rangkaian hambatan seri bertujuan memperbesar nilai hambatan sehingga jika hambatan $C$ ditingkatkan akan semakin mempengaruhi nyala lampu $A$ dan $B$ sebagaimana diketahui bahwa kuat arus berbanding terbalik dengan hambatan.

Persentasi kesalahan dalam mengungkapkan alasannya sebesar $51,43 \%$. Responden yang memilih jawaban yang benar yaitu $A$ dan $B$ menurun mengemukakan alasan yang salah bahwa ketika hambatan ditingkatkan maka arus pada lampu A dan B akan menurun. Hal ini tidak sesuai dengan konsep dari arus listrik pada rangkaian bahwa besarnya kuat arus listrik pada rangkaian seri nilanya tetap. Tingginya persentasi responden yang memiliih pilihan A bahwa nyala lampu A akan tetap sedangkan lampu B akan menurun sebesar $31,43 \%$. Umumnya responden menjelaskan bahwa lampu A akan tetap sama sedangkan lampu B akan menurun. Hal ini dikarenakan arus pada lampu $B$ telah melewati sebuah hambatan $\mathrm{C}$ sedangkan lampu $\mathrm{A}$ tetap karena belum melewti hambatan.

\section{KESIMPULAN}

Berdasarkan hasil dan pembahasan diperoleh kesimpulan sebagai berikut:

1. Siswa beranggapan tidak adanya pengaruh dari hubungan singkat pada rangkaian listrik.

2. Siswa beranggapan bahwa adanya arus listrik yang mengalir dalam kawat walaupun saklar diputuskan.

3. Siswa beranggapan bahwa besarnya tegangan pada rangkaian seri dan paralel adalah sama sehingga menganggap besarnya daya pada rangkaian adalah sama.

4. Siswa tidak mengetahui tentang konsep Hukum Kirchoff 1 dan beranggapan bahwa besarnya arus listrik yang mengalir dalam rangkaian paralel di semua titik adalah sama.

5. Siswa tidak mengetahui tentang konsep medan listrik pada rangkaian listrik. 
6. Siswa beranggapan bahwa besarnya kuat arus yang melewati hambatan pada rangkaian seri dan paralel adalah sama.

7. Siswa beranggapan beda potensial pada baterai berbanding lurus dengan kuat arus berdasarkan Hukum Ohm.

8. Siswa beranggapan bahwa hambatan berbanding lurus dengan kuat arus pada rangkaian seri.

Berdasarkan hasil yang didapatkan saat penelitian tentang konsepsi siswa, hendaknya perlu adanya pendalaman konsep yang berkaitan dengan rangkaian listrik arus searah. Perlu adanya perlakukan khusus kepada siswa untuk menggali ulang konsepsi yang telah mereka peroleh dari pembelajaran sebelumnya atau lingkungan sekitar sebelum proses pembelajaran yang berhubungan dengan rangkaian listrik arus searah di SMA dilaksanakan.

\section{PUSTAKA RUJUKAN}

[1] Pardhan, H \& Bano,Y. 2001. Science teachers' alternate conceptions about direct-currents, Internasional Journal Science Education, Vol. 23, 301-318.

[2] Saleh, S. 2011. The Level of B.Sc.Ed Students' Conceptual Understanding of Newtonian Physics. International Journal of Academic Research in Business and Social Sciences, Vol. 1, No. 3.

[3] Engelhardt P. V. and Beichner, R. J. 2004, Students' understanding of direct current resistive electrical circuits, Amerikan Journal Physics, Vol. 72, 98

[4] Küçüközer, H. \& Kocakülah, S. 2007. Secondary School Students Misconceptions

About Simple Electric Circuits. Journal of Turkish Science Education Vol. 3.

[5] Hermawan, H. 2008. Identifikasi Miskonsepsi Siswa Pada Konsep Sistem Reproduksi Manusia dengan Menggunakan Tes Diagnostik Pilihan Ganda Beralasan. Skripsi. FKIP UPI.

[6] Lukman Abdul. 2011. Model Mental Siswa Dalam Memahami Perubahan Wujud. Jurnal Penelitian dan Pendidikan, Vol. 8, No.1.

[7] Engelhardt P. V. and Beichner, R. J. 2004, Students' understanding of direct current resistive electrical circuits, Amerikan Journal Physics, Vol. 72, 98-115.

[8] Bilal, E \& Esra, M. 2009. Investigating Student's Conceptions of Some Electricity Concepts. Turkey Journal of Physics. Latin American Journal Physics

Education, Vol. 3, No.2. 